\title{
OPTIMASI RUTE PANDUAN INFORMASI LOKASI WISATA MENGGUNAKAN ANT COLONY SYSTEM PADA KOTA BATAM
}

\author{
Alfannisa Annurrallah Fajrin'), Delia Meldra ${ }^{2)}$ \\ ${ }^{1}$ Teknik Komputer, Universitas Putera Batam, Jl.R.Soeprapto \\ email: asykharit1302@gmail.com \\ ${ }^{2}$ Teknik Komputer, Universitas Putera Batam, Jl.R.Soeprapto \\ email: dmeldra@gmail.com
}

\begin{abstract}
Abstrak
Banyaknya wisatawan yang berkunjung ke kota batam baik wisatawan dalam negri ataupun luar negri untuk menghabiskan waktu liburan mereka dikarenakan biaya hidup dan barang yang lebih murah daripada daerah lain dikarenakan batam merupakan wilayah FTZ (free tax Zone). Sehingga kota batam menjadi wilayah surga belanja bagi masyarakat sekitar pulau batam ataupun luar Batam. Batam sendiri mempunyai beberapa destinasi belanja dan tempat berkunjung untuk para wisatawan. Dengan melimpahnya destinasi wisata pada kota batam, baik wisata belanja maupun wisata alamnya, tidak jarang para wisatawan mengalami berbagai permasalahan dalam menggunjungi negara tersebut, salah satu permasalahan sederhana yang dialami adalah masalah efisiensi waktu dan biaya dalam melakukan wisata ke kota batam. Permasalah yang dapat kita selesaiakan dalam penelitian ini adalah membantu wisatawan atau turis tidak mengalami kesulitan saat mengunjungi tempat-tempat wisata di Batam dengan cara menggunakan Algoritma ant colony dalam pemilihan jalur yang efisien. Model Waterfall dalam SDLC merpuakan proses yang akan digunakan dalam penelitian ini untuk bisa mendapatkan hasil terbaik.
\end{abstract}

Kata Kunci : Algoritma Ant Colony, Wisata Batam, Waterfall

\section{Abstract}

The number of tourists visiting the city of Batam both domestic and foreign tourists to spend their vacation time because the cost of living and goods are cheaper than other areas because batam is an FTZ area (free tax Zone). So that the city of Batam has become a shopping paradise for the people around Batam or outside Batam. Batam itself has several shopping destinations and places to visit for tourists. With the abundance of tourist destinations in the city of Batam, both shopping and nature tourism, it is not uncommon for tourists to experience various problems in visiting the country, one of the simple problems experienced is the problem of time and cost efficiency in conducting tours to the city of Batam. The problem that we can solve in this research is to help tourists or tourists not experience difficulties when visiting tourist attractions in Batam by using the ant colony algorithm in efficient path selection. The Waterfall Model in SDLC is a process that will be used in this study to get the best results.

Keywords: Ant Colony Algorithm, Batam Tourism, Waterfall 


\section{PENDAHULUAN}

Perkembangan yang terjadi pada kota Batam sangat mempengaruhi jumlah kunjungan para wisatawan dari dalam atau luar negri Mereka memilih berlibur ke Batam dengan alasan Batam merupakan surganya belanja, karena Batam merupakan wilayah FTZ atau Free Tax Zone dimana barang yang ada di Batam tidak dikenakan pajak. Singapur dan Malaysia berbatasan langsung dengan Batam, sehingga kota batam juga menjadi pintu masuk maupun keluar oleh wisatawan yang ingin berkunjung ke negara malaysia dan singapura,wisatawan lokal maupun mancanegara yang berkunjung pun sebagian besar sudah pernah ke batam baik untuk keperluan bisnis maupun sekedar berlibur (Chan \& Sari, 2017).

Beberapa wilayah yang sering dikunjungi oleh para wisatawan adalah kawasan belanja seperti Nagoya, Jodoh, dan lain-lain. Wisata alampun tak kalah menarik, seperti Nongsa, Jembatan Barelang, dan lain-lain. Wisata kuliner di Batam yang sering dicari oleh wisatawan adalah makanan seafood karena Batam merupakan daerah kepulauan. Dengan banyaknya destinasi wisata yang bias dikunjungi, para wisatawan tak jarang menghabiskan waktu untuk memilih tempat, biaya, dan rute untuk ke tempat wisata tersebut.

Wisatawan seringkali tidak mempunyai banyak waktu dan biaya untuk mengunjungi lokasi wisata secara sekaligus, agar tidak mengeluarkan biaya terlalu besar atau memakan waktu banyak dijalan karena tidak mengerti rute atau jalan mana yang akan ditempuh. Pemilihan rute perjalanan wisata dan berbelanja yang baik dapat meminimalisir hal - hal yang tidaj diinginkan oleh para wisatawan seperti tersesat atau kehilangan arah.

Salah satu cara untuk menanggulanginya, permaslahan akan dibahas menggunakan algoritma Ant Colony yang nantinya akan membantu para wisatawan yang akan menuju ketempat wisata atau tempat berbelanja di kota Batam, Kepuluan Riau.

\section{TINJAUAN PUSTAKA}

\subsection{Sistem Penunjang Keputusan}

Sistem pendukung keputusan adalah sekumpulan elemen yang saling berhubungan untuk membentuk suatu kesatuan dalam proses pemilihan berbagai alternatif tindakan guna menyelesaikan suatu masalah, sehingga masalah tersebut dapat diselesaikan secara efektif dan efisien (Khoiriah, 2013). Ada beberapa tujuan dari Sistem Pendukung Keputusan adalah :

1. Membantu manajer dalam pengambilan keputusan atas masalah semistruktur

2. Memberikan dukungan atas pertimbangan manajer dan bukannya dimaksudkan untuk menggantikan fungsi manajer

3. Peningkatan produktivitas

4. Berdaya saing

System penunjang keputusan merupakan system informasi yang menyediakan informasi dan pemodelan dalam setiap penelitian. Sistem pendukung keputusan biasanya dibangun untuk mendukung solusi atas suatu masalah atau untuk mengevakuasi suatu peluang. Sistem pendukung keputusan seperti ini disebut aplikasi sistem pedukung keputusan. Aplikasi system pendukung keputusan digunakan dalam pengambilan keputusan dalam suatu permasalahan.Aplikasi system pendukung keputusan menggunakan CBIS(computer based information system) yang fleksibel, interaktif dan dapat diadaptasi serta dikembangkan 
dalam mendukung solusi atas masalah manajemen spesifikasi yang tidak terstruktur (Singkil, 2015).

\subsection{Data Mining}

Data mining dan knowledge discovery in database (KDD) sering kali digunakan secara bergantian untuk menjelaskan proses penggalian informasi tersembunyi dalam suatu basis data yang besar. Sebenarnya kedua istilah tersebut memiliki konsep yang berbeda, tetapi berkaitan satu sama lain(Angga Ginanjar Mabrur, 2012).

Data mining merupakan proses untuk menemukan hubungan baru yang mempunyai sebuah pola dan kebiasaan dengan memilih data dan dsimpan menggunakan teknologi pengenalan pola seperti statistic dan matematika, karena data mining juga gabungan dari beberapa disiplin ilmu.

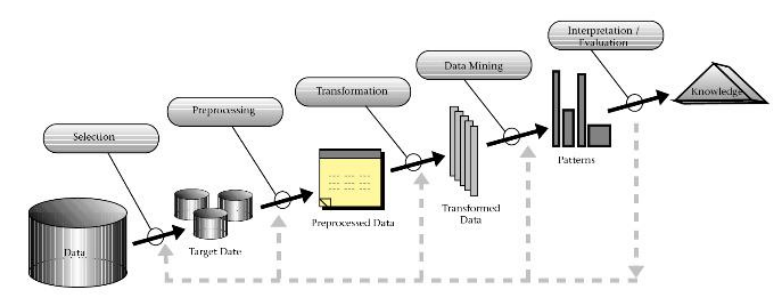

Gambar 2.1 KDD

\subsection{Algoritma Ant Colony}

ACO adalah teknik pencarian multi agent untuk menyelesaikan permasalahan kombinatorial dan persoalan yang lain yang di inspirasi tingkah laku semut dalam suatu koloni. Algoritma ini di inspirasi oleh tingkah laku koloni semut, bagaimana hewan yang hampir buta dengan kemampuan individu yang sederhana dapat menemukan jalan terpendek (sarang semut dengan sumber makanan) jika bersama dalam suatu koloni (Maryati \& Wibowo, 2012).

Pada awalnya semut akan mengelilingi daerah sekitar sarangnya dengan acak, begitu mengetahui ada makanan semut itu akan mengenali kualitas dan kuantitas makanan tersebut dan membawa beberapa bagian ke sarangnya. dalam perjalanannya mereka akan meninggalkan jejak zat kimia pheromone di dasarnya.

Pheromone ini akan membimbing semut lain untuk menemukan sumber makanan, banyaknya pheromone yang ditinggalkan oleh semut tergantung jumlah makanan yang ditemukan. Semakin banyak semut yang melewati semakin kuat jejak pheromone yang ditinggalkan, untuk lebih jelasnya perhatikan gambar berikut(Chen, Xiao, Li, Wang, \& Huo, 2018).

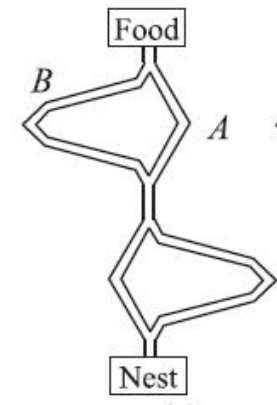

(a)

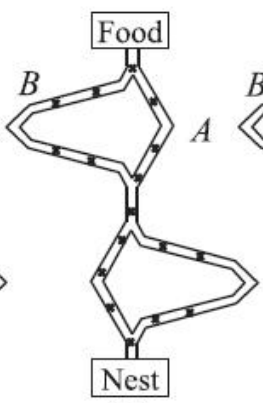

(b)

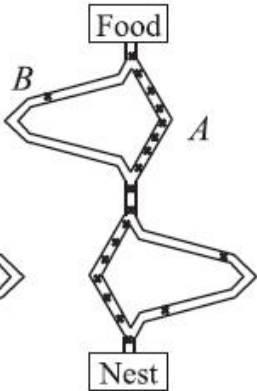

(c)

Gambar 2.2 Ant Colony Algorithm 
gambar di atas menunjukkan bagaimana semut dapat menemukan jalan terpendek.
a. Semut melewati jalan antara titik E dan A.
b. Terdapat benda yang menghalangi jalan, semut dapat memilih dua jalan yang berbeda dengan probabilitas yang sama.
c. Pheromone pada jalan terpendek lebih banyak.

Ant System yang ada dalam hal ini adalah ACO yang diterapkan pada TSP (Traveling Salesman Problem). Permasalahan pada TSP adalah bagaimana mengunjungi n kota dengan seminimal mungkin dimana setiap kota hanya boleh dikunjungi sekali. Langkah-langkahnya adalah :

a. setiap semut membangun solusi dari kota awal yang dipilih secara acak.

b. kota berikutnya dipilih berdasarkan probabilitas dengan formula tertentu.

c. pheromone trail $\tau(\mathrm{i}, \mathrm{j})$ mendefinisikan kecenderungan mengunjungi kota $\mathrm{j}$ setelah mengunjungi kota $i$

d. $\eta(i, j)$ merupakan informasi heuristic yang digunakan, yaitu perbandingan terbalik jarak kota I dan kota j.

e. pheromone trail dirubah setelah setiap semut telah mengunjungi seluruh kota.

f. Pheromone trail akan menguap tergantung parameter $\rho$ (parameter evaporation)

Pada saat sistem (lingkungan semut) telah menemukan solusi yang optimal, yaitu lintasan terpendek, maka ACO akan dapat beradaptasi dengan cepat terhadap perubahan yang terjadi di sekitar. Adaptasi ini didasarkan pada pheromone yang merupakan dasar dari ant-system.

Pheromone yang lebih kuat akan dimiliki oleh solusi dengan jalur yang lebih optimal pada akhir suatu algoritma. ACO dalam prosesnya dimulai dengan semut secara individual memiliki kemampuan kognitif terbatas secara kolektif mampu menemukan jalur terpendek antara sumber makanan dan sarang. Misalkan terdapat N semut dalam satu koloni. Semutsemut memulai perjalanan dari sarang menuju sumber makanan dengan melalui beberapa titik dan berakhir pada titik akhir setiap siklus atau iterasi. Jika semua semut sudah menyelesaikan perjalanannya

Proses optimasi berakhir jika jumlah iterasi maksimum sudah tercapai atau tidak ada lagi solusi yang lebih baik yang bisa didapatkan dalam beberapa iterasi yang berurutan.

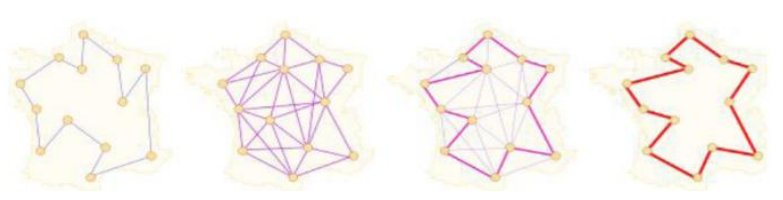

Gambar 2.3. Ant Colony algorithm

\subsection{Klasifikasi}

Dalam klasifikasi mempunyai beberapa variable target tertentu. Dalam klasifikasi terdapat target variable kategori. Metode-metode / model-model yang telah dikembangkan oleh periset untuk menyelesaikan kasus klasifikasi antara lain (Zulkifli, 2016): 
1. Pohon keputusan

2. Pengklasifikasi bayes/naive bayes

3. Jaringan saraf tiruan

4. Analisis statistik

5. Algoritma genetik

6. Rough sets

7. Pengklasifikasi k-nearest neighbour

8. Metode berbasis aturan

9. Memory based reasoning

10. Support vector machine

\section{d. Pariwisata}

Pariwisata adalah perjalanan dari satu tempat ke tempat lain bersifat sementara, dilakukan perorangan atau kelompok, sebagai usaha mencari keseimbangan dan kebahagiaan dengan lingkungan hidup dalam dimensi sosial, budaya, alam,dan ilmu.

Pariwisata harus memenuhi empat kriteria di bawah ini, yaitu :

1. perjalanan dilakukan dari suatu tempat ke tempat lain, perjalanan dilakukan di luar tempat kediaman dimana orang itu biasanya tinggal

2. tujuan perjalanan dilakukan semata-mata untuk bersenang-senang, tanpa mencari nafkah di negara, kota atau tujuan yang dikunjungi.

3. uang yang dibelanjakan wisatawan tersebut dibawa dari negara asalnya, dimana dia bisa tinggal atau berdiam, dan bukan diperoleh karena hasil usaha selama dalam perjalanan wisata yang dilakukan.

4. perjalanan dilakukan minimal 24 jam atau lebih.

\section{METODE PENELITIAN}

\subsection{Rancangan Penelitian}

Dalam pengumpulan data di penelitianini yang digunakan adalah :

a. Penelitian LapanganPenelitian yang secara langsungdilakukan untuk mengetahui apa yangterjadi sekarang, yang dimanaberkaitan dengan penelitian ini.

b.Penelitian KepustakaanMetode pengumpulan datakepustakaan dilakukan denganmengumpulkan data-data dari sumberatau buku yang relevan terhadappenelitian.

c. Penelitian membaca buku, jurnal danartikel yang berhubungan dengankaryawan berprestasi danmengumpulkan data - data.

d. Metode wawancaraMetode wawancara dilakukan dengancara tatap muka dan menanyakanlangsung kepada objek yang pernahmelakukan penelitian sebelumnya.

\subsection{Analisa Sistem}

Menginput data koordinat titik dan jarakantar titik menetapkan parameter algoritmayang dimana menggunakan analisa heuristic untuk menyelesaikan masalah lintasan menggunakan graf sederhana. Dalam penelitian ini yang akan kita lihat lintasannya adalah untuk tujuan yang paling sering dikunjungi. 


\section{HASIL DAN PEMBAHASAN}

Penelitan ini melakukan pengumpulan data dan bahan-bahan sesuai dengan yang dibutuhkan, agar pada saat melakukan penelitian berjalan dengan lancar. Perhitungan algoritma semut terdiri dari probab dalam menentukan perjalanan yang akan ditempuh dalam beberapa waktu. Penelitian ini memilih 7 titik lokasi wisata favorit yang sering dikunjungi dan mudak dikenali oleh google map, yaitu :

1. Nagoya Hill

2. Taman Engku Putri

3. Ocarina Park

4. Kebun Raya Batam

5. Jembatan Barelang

6. Nongsa

7. Bukit Senyum

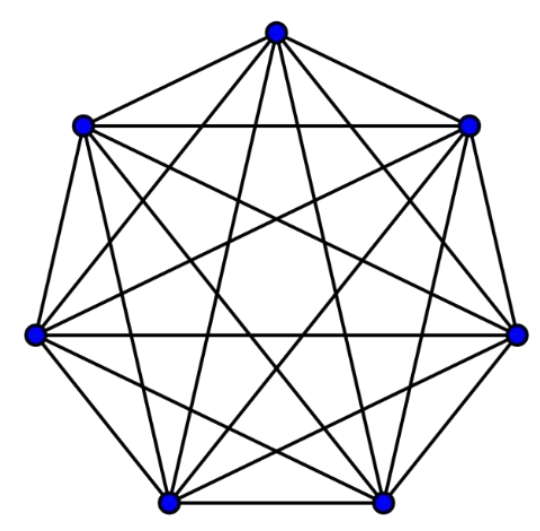

Gambar 4.1. Graft 7 lokasi wisata

Berdasarkan data yang didapatkan dari hasil pencarian dengan bantuan tool penunjuk arah pada Google Map maka dapat disusun jarak tempuh $(\mathrm{km})$ dari masing-masing titik pada tabel sebagai berikut:

Tabel 4.1. Jarak Tempuh Masing-masing Lokasi wisata

\begin{tabular}{|c|c|c|c|c|c|c|c|}
\hline Titik Lokasi (KM) & A & B & C & D & E & F & G \\
\hline A & 0 & 6.2 & 8.9 & 27.8 & 24.7 & 21.7 & 1.8 \\
\hline B & 6.2 & 0 & 4.5 & 21.5 & 21 & 15.4 & 8 \\
\hline C & 8.9 & 4.5 & 0 & 25.5 & 27.2 & 19.5 & 9.7 \\
\hline D & 27.8 & 21.5 & 25.5 & 0 & 38.4 & 5.7 & 30.5 \\
\hline E & 24.7 & 21 & 27.2 & 38.4 & 0 & 31.7 & 26.5 \\
\hline F & 21.7 & 15.4 & 19.5 & 5.7 & 31.7 & 0 & 23.1 \\
\hline G & 1.8 & 8 & 9.7 & 30.5 & 26.5 & 23.1 & 0 \\
\hline
\end{tabular}

Selanjutnya yaitu menggunakan algoritma semut untuk mendapatkan jalur terpendek (optimal). Langkah pertama yang dilakukan yaitu inisialisasi harga parameter-parameter algoritma, parameter-parameter yang digunakan yaitu: 


$$
\begin{aligned}
& \text { Alpha }=1,00 \\
& \text { Beta }=1.00 \\
& \text { Phi }=0.10
\end{aligned}
$$

$\operatorname{Banyak} \operatorname{semut}(k)=7$

Tahapan dalam menggunakan algoritma ant colony yaitu:

1. Memilih titik awal yaitu titik V1

2. V1 memiliki jalur di V2, V3, V4, V5, V6, dan V7, masing-masing dengan jarak (4.9), (5.3), (4.8), (5.5), (3.7) dan (1.6) selanjutnya diambil jarak minimal atau paling kecil sehingga yang terpilih yaitu V7 sehingga diperoleh jalur pertama yaitu $\mathrm{V} 1 \rightarrow \mathrm{V} 7$

3. Melakukan cara yang sama dengan langkah kedua dimana dimulai dari titik yang terpilih yaitu V7 . V7 memiliki jalur di V2, V3, V4, V5, dan V6 masing masing dengan jarak (6), (6.5), (6), (4.7) dan (2.3). Selanjutnya diambil jarak minimal atau paling kecil sehingga yang terpilih yaitu V4 sehingga diperoleh jalur kedua yaitu $\mathrm{V} 1 \rightarrow \mathrm{V} 7 \rightarrow \mathrm{V} 6$

4. Melakukan cara yang sama dengan langkah ketiga dimana dimulai dari titik yang terpilih yaitu V6 . V6 memiliki jalur di V2, V3, V4, dan V5 masing-masing dengan jarak (1,6), (6.5), (6) dan (6.6) Selanjutnya mengambil jarak minimal atau paling kecil sehingga yang terpilih yaitu V3 sehingga diperoleh jalur ketiga yaitu $\mathrm{V} 1 \rightarrow \mathrm{V} 7 \rightarrow \mathrm{V} 6 \rightarrow \mathrm{V} 2$

5. Melakukan cara yang sama dengan langkah keempat dimana dimulai dari titik yang terpilih yaitu V2 . V2 memiliki jalur di V3, V4, dan V5 masing-masing dengan jarak (3.5), (1.2) dan (1.4) Selanjutnya mengambil jarak minimal atau paling kecil sehingga yang terpilih yaitu V2 sehingga diperoleh jalur keempat yaitu $\mathrm{V} 1 \rightarrow \mathrm{V} 7 \rightarrow \mathrm{V} 6 \rightarrow \mathrm{V} 2 \rightarrow \mathrm{V} 4$

6. Melakukan cara yang sama dengan langkah kelima dimana dimulai dari titik yang terpilih yaitu V4 . V4 memiliki jalur di V3, dan V5 masing-masing dengan jarak (2.6) dan (2,7) Selanjutnya mengambil jarak minimal atau paling kecil sehingga yang terpilih yaitu V3 sehingga diperoleh jalur keempat yaitu $\mathrm{V} 1 \rightarrow \mathrm{V} 7 \rightarrow \mathrm{V} 6 \rightarrow \mathrm{V} 2 \rightarrow \mathrm{V} 4 \rightarrow \mathrm{V} 3$

Selanjutnya karena sudah tidak ada titik lagi maka titik yang terakhir yaitu V5 sehingga diperoleh jalur $\mathrm{V} 1 \rightarrow \mathrm{V} 7 \rightarrow \mathrm{V} 6 \rightarrow \mathrm{V} 2 \rightarrow \mathrm{V} 4 \rightarrow \mathrm{V} 3 \rightarrow \mathrm{V} 5$. karena Travelling Salesman Problem berawal dari titik awal dan berakhir dititik awal juga, maka diperoleh jalur $\mathrm{V} 1 \rightarrow \mathrm{V} 7 \rightarrow \mathrm{V} 4 \rightarrow \mathrm{V} 3 \rightarrow \mathrm{V} 2 \rightarrow \mathrm{V} 5 \rightarrow \mathrm{V} 6 \rightarrow \mathrm{V} 1$ sehingga diperoleh jarak minimal Cgreedy $=1.8+6+27.8+25.5+4.5+21+31.7=134$.

Selanjutnya dari algoritma Greedy diatas sehingga didapatkan feromon awal

$$
\tau_{i j}=\tau_{0} \quad=\frac{7}{134}=0.052239
$$


$\mathrm{Hal}: 1-13$

Langkah kedua yaitu mencari nilai visibilitas antara titik dengan menggunakan rumus $\eta_{i j}=1 / d_{i j}$ dimana merupakan jarak antara titik yang telah diketahui. Sehingga didapatkan:

$$
\begin{aligned}
\mu 1,2=\frac{1}{d 1,2}=\frac{1}{6.2}=0.161 & \\
\mu 1,3 & =\frac{1}{d 1,3}=\frac{1}{8.9}=0.112 \\
\mu 1,4 & =\frac{1}{d 1,4}=\frac{1}{27.8}=0.035 \\
\mu 1,5 & =\frac{1}{d 1,5}=\frac{1}{24.7}=0.040 \\
\mu 1,6 & =\frac{1}{d 1,6}=\frac{1}{21.7}=0.046 \\
\mu 1,7 & =\frac{1}{d 1,7}=\frac{1}{1.8}=0.555
\end{aligned}
$$

Dengan cara yang sama diperoleh nilai visibilitas antara titik sebagai berikut:

Tabel 4.2. Visibilitas invers antar titik

\begin{tabular}{|c|c|c|c|c|c|c|c|}
\hline & $\mathbf{A}$ & $\mathbf{B}$ & $\mathbf{C}$ & $\mathbf{D}$ & $\mathbf{E}$ & $\mathbf{F}$ & $\mathbf{G}$ \\
\hline $\mathbf{A}$ & 0 & 0.16129 & 0.11236 & 0.035971 & 0.040486 & 0.046083 & 0.555556 \\
\hline $\mathbf{B}$ & 0.16129 & 0 & 0.222222 & 0.046512 & 0.047619 & 0.064935 & 0.125 \\
\hline $\mathbf{C}$ & 0.11236 & 0.222222 & 0 & 0.039216 & 0.036765 & 0.051282 & 0.103093 \\
\hline $\mathbf{D}$ & 0.03597 & 0.046512 & 0.039216 & 0 & 0.026042 & 0.175439 & 0.032787 \\
\hline $\mathbf{E}$ & 0.04049 & 0.047619 & 0.036765 & 0.026042 & 0 & 0.031546 & 0.037736 \\
\hline F & 0.04608 & 0.064935 & 0.051282 & 0.175439 & 0.031546 & 0 & 0.04329 \\
\hline $\mathbf{G}$ & 0.55556 & 0.125 & 0.103093 & 0.032787 & 0.037736 & 0.04329 & 0 \\
\hline
\end{tabular}

Perjalanan semut berlangsung terus menerus sampai semua titik telah dikunjungi dan membentuk suatu jalur. Berikut perhitungan probabilitas untuk siklus ke-1 $(N C=1)$

Siklus ke-1 $(N C=1)$

\section{Semut ke-1 $(k 1)$}

Tabu list $=\mathrm{V} 1$ 


$$
P_{i j}^{k}=\left\{\frac{\left[\tau_{i j}\right]^{\alpha}\left[\eta_{i j}\right]^{\beta}}{\sum_{u \in j_{r}^{k}}\left[\tau_{i k}\right]^{\alpha}\left[\eta_{i}\right]^{\beta}}\right.
$$

Titik V1 $P_{i j}^{1}:=0.00$

$$
\begin{aligned}
P_{i j}^{1}: \frac{\left[\tau_{i j}\right]^{\alpha}\left[\eta_{i j}\right]^{\beta}}{\sum_{u \in j_{r}^{k}}\left[\tau_{i k}\right]^{\alpha}\left[\eta_{i}\right]^{\beta}} \quad \operatorname{TitikV2} \\
=\frac{(0.1612) 1.00 *(0.052) 1.00}{0.0468}=0.1694
\end{aligned}
$$

$$
\begin{array}{ll}
\text { TitikV3 } & =\frac{(0.052) 1.00 *(0.1123) 1.00}{0.0468}=0.1180 \\
\text { TitikV4 } & =\frac{(0.052) 1.00 *(0.0359) 1.00}{0.0468}=0.0377 \\
\text { TitikV5 } & =\frac{(0.052) 1.00 *(0.0404) 1.00}{0.0468}=0.0425 \\
\text { TitikV6 } & =\frac{(0.052) 1.00 *(0.0460) 1.00}{0.0468}=0.0484 \\
\text { TitikV7 } & =\frac{(0.0525) 1.00 *(0.5555) 1.00}{0.0468}=0.5837
\end{array}
$$

Tabel 4.3. Probabilitas Semut ke 1 dari titik V1 Ke lokasi lain

\begin{tabular}{|c|r|r|r|r|r|r|r|}
\hline & \multicolumn{1}{|c|}{ vl } & \multicolumn{1}{c|}{ v2 } & v3 & v4 & v5 & \multicolumn{1}{c|}{ v6 } & \multicolumn{1}{c|}{ 7 } \\
\hline v1 & 0 & 0.1694 & 0.118 & 0.0377 & 0.0425 & 0.0484 & 0.5837 \\
\hline Probabilitas Komulatif & 0 & 0.1694 & 0.2874 & 0.3251 & 0.3676 & 0.416 & 1 \\
\hline
\end{tabular}

Begitulah perhitungan dalam algoritma ant colony terhadap titik 1 hingga titik ke 7.

Bilangan random yang dibangkitkan antara 0-1 dengan menggunakan fungsi Excel yaitu Rand() maka terpilih 0.084 sehingga titik yang terpilih yaitu V2 sehingga Tabu list menjadi $\mathrm{V} 7 \rightarrow \mathrm{V} 2$. Lakukan langkah yang sama untuk semut ke-7 yang dimulai dari titik V7

Setelah didapatkan semua rute untuk perjalanan semut yang pertama maka dapat disusun table sebagai berikut: 
Tabel 4.10. Perjalanan Semut

\begin{tabular}{|c|c|c|c|c|c|c|c|c|c|c|}
\hline Semut & Titik & \multicolumn{6}{|c|}{ Probabilitas } & Titik & Tabu \\
terpilih & List \\
\cline { 3 - 9 } & Awal & V1 & V2 & V3 & V4 & V5 & V6 & V7 & V1 V6 \\
\hline$K 1$ & V1 & 0 & 0.1694 & 0.118 & 0.0377 & 0.0425 & 0.0484 & 0.5837 & V6 & V \\
\hline$K 2$ & V2 & 0.241605 & 0 & 0.33287 & 0.06967 & 0.07133 & 0.0972 & 0.1872 & V3 & V2 $\rightarrow$ V3 \\
\hline$K 3$ & V3 & 0.1988 & 0.3933 & 0 & 0.0694 & 0.065 & 0.0907 & 0.1824 & V5 & V3 $\rightarrow$ V5 \\
\hline$K 4$ & V4 & 0.101 & 0.1306 & 0.1101 & 0 & 0.0731 & 0.4928 & 0.0921 & V2 & V4 $\rightarrow$ V2 \\
\hline$K 5$ & V5 & 0.1838 & 0.2162 & 0.1669 & 0.1182 & 0 & 0.1432 & 0.1713 & V4 & V5 $\rightarrow$ V4 \\
\hline$K 6$ & V6 & 0.1116 & 0.1573 & 0.1242 & 0.4252 & 0.0764 & 0 & 0.1049 & V1 & V6 $\rightarrow$ V1 \\
\hline$K 7$ & V7 & 0.619 & 0.1392 & 0.1148 & 0.0365 & 0.042 & 0.0482 & 0 & V2 & V7 $\rightarrow \mathrm{V} 2$ \\
\hline
\end{tabular}

Langkah selanjutnya yaitu melanjutkan perjalanan kedua dengan cara yang sama dengan sebelumnya yang dimana semut ke-1 $(k l)$ diawali dari titik yang terpilih dalam hal ini V6, semut ke-2 $(k 2)$ diawali dari titik V3, semut ke-3 $(k 3)$ diawali dari titik V5 . semut ke-4 $(k 4)$ diawali dari titik V2, semut ke-5 (k5) diawali dari titik V4, semut ke-6 (k6) diawali dari titik V1, semut ke-7 $(k 7)$ diawali dari titik V2. Kemudian rute yang sudah dikunjungi dalam tabu list sudah tidak digunakan lagi dalam perhitungan sehingga diperoleh tabel perjalanan kedua semut:

Tabel 4.11. Perjalanan Semut kedua

\begin{tabular}{|c|c|c|c|c|c|c|c|c|c|c|}
\hline \multirow{2}{*}{ Semut } & \multirow{2}{*}{$\begin{array}{l}\text { Titik } \\
\text { Awal }\end{array}$} & \multicolumn{7}{|c|}{ Probabilitas } & \multirow{2}{*}{$\begin{array}{c}\text { Titik } \\
\text { terpilih }\end{array}$} & \multirow{2}{*}{ Tabu List } \\
\hline & & $\mathrm{Vl}$ & $\mathrm{V} 2$ & $\mathrm{~V} 3$ & $\mathrm{V4}$ & $\sqrt{5}$ & $\mathrm{~V} 6$ & $\mathrm{V7}$ & & \\
\hline$K I$ & $\mathrm{~V} 1$ & 0 & 0.178 & 0.124 & 0.0397 & 0.0447 & 0 & 0.6134 & $\mathrm{V7}$ & $\begin{array}{c}\mathrm{V1} \rightarrow \\
\mathrm{V} 6 \rightarrow \mathrm{V7}\end{array}$ \\
\hline$K 2$ & $V_{2}$ & 0.3621 & 0 & 0 & 0.1044 & 0.1069 & 0.1458 & 0.2806 & $\mathrm{V1}$ & $\begin{array}{c}\mathrm{V} 2 \rightarrow \\
\mathrm{V} \rightarrow \mathrm{V} 1\end{array}$ \\
\hline $\mathrm{KI}$ & $V_{3}$ & 0.2127 & 0.4207 & 0 & 0.0742 & 0 & 0.097 & 0.1951 & $\mathrm{~V} 1$ & $\underset{\mathrm{V} 3 \rightarrow \mathrm{VI}}{\mathrm{VS}}$ \\
\hline K4 & V4 & 0.1162 & 0 & 0.1267 & 0 & 0.0841 & 0.5669 & 0.1059 & 16 & $\begin{array}{c}\mathrm{V} 4 \rightarrow \\
\mathrm{V} 2 \rightarrow \mathrm{V} 6\end{array}$ \\
\hline$K$ & v5 & 0.2085 & 0.2452 & 0.1893 & 0 & 0 & 0.1624 & 0.1943 & V2 & $\mathrm{V}_{5} \rightarrow \mathrm{VH} \rightarrow \mathrm{V} 2$ \\
\hline K6 & $V_{6}$ & 0 & 0.1771 & 0.1399 & 0.4786 & 0.086 & 0 & 0.1181 & V5 & $\begin{array}{l}\mathrm{V} 6 \rightarrow \\
\mathrm{V} 1 \rightarrow \mathrm{V} 5\end{array}$ \\
\hline$K>$ & $\mathrm{V} 7$ & 0.7192 & 0 & 0.1334 & 0.4244 & 0.0488 & 0.5604 & 0 & V3 & $\begin{array}{c}\mathrm{V} 7 \rightarrow \\
\mathrm{V} 2 \rightarrow \mathrm{V}^{3}\end{array}$ \\
\hline
\end{tabular}

Karena seluruh kota sudah dikunjungi untuk pembangunan solusi siklus pertama $(\mathrm{NC}=1)$ dan berdasarkan pengertian, Travelling salesman problem bahwa dimulai dari titik awal dan berakhir dititik awal pula maka dapat diperoleh daftar perjalanan semut untuk siklus pertama sebagai berikut: 
Tabel 4.16. Rute Perjalanan Semut dan penambahan Feromonnya

\begin{tabular}{|c|c|c|c|}
\hline Semut & Tabu List & Panjang & $\Delta \mathbf{i}, \mathbf{k}$ \\
\hline KI & 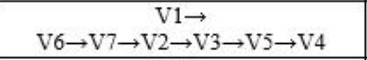 & 122.9 & 0.008137 \\
\hline$K 2$ & $\underset{\mathrm{V} 3 \rightarrow \mathrm{V} 1 \rightarrow \mathrm{V} 7 \rightarrow \mathrm{V} 5 \rightarrow \mathrm{V} 4 \rightarrow \mathrm{V} 6}{ }$ & 85.8 & 0.011655 \\
\hline K3 & $\underset{\mathrm{V} 5 \rightarrow \mathrm{V} 1 \rightarrow \mathrm{V} 4 \rightarrow \mathrm{V} 2 \rightarrow \mathrm{V} 6 \rightarrow \mathrm{V} 7}{c}$ & 139.7 & 0.007158 \\
\hline K4 & $\underset{\mathrm{V} 2 \rightarrow \mathrm{V} 6 \rightarrow \mathrm{V} 3 \rightarrow \mathrm{V} 7 \rightarrow \mathrm{V} 1 \rightarrow \mathrm{V} 5}{c}$ & 92.6 & 0.010799 \\
\hline K5 & $\mathrm{V} 5 \rightarrow \mathrm{V} 4 \rightarrow \mathrm{V} 2 \rightarrow \mathrm{V} 6 \rightarrow \mathrm{V} 1 \rightarrow \mathrm{V} 3 \rightarrow \mathrm{V} 7$ & 115.6 & 0.008651 \\
\hline K6 & $\underset{\mathrm{V} 1 \rightarrow \mathrm{V} 5 \rightarrow \mathrm{V} 3 \rightarrow \mathrm{V} 2 \rightarrow \mathrm{V} 7 \rightarrow \mathrm{V} 4}{\mathrm{~V}}$ & 116.6 & 0.008576 \\
\hline K7 & $\underset{\mathrm{V} 2 \rightarrow \mathrm{V} 3 \rightarrow \mathrm{V} 1 \rightarrow \mathrm{V} 4 \rightarrow \mathrm{V} 5 \rightarrow \mathrm{V} 6}{x}$ & 119.3 & 0.008382 \\
\hline
\end{tabular}

Untuk siklus pertama $(\mathrm{NC}=1)$ diperoleh rute terbaik yaitu rute yang ditempuh oleh semut $k 1$ dengan panjang rute sebesar $85.8 \mathrm{~km}$ dengan rute $\mathrm{V} 2 \rightarrow \mathrm{V} 3 \rightarrow \mathrm{V} 1 \rightarrow \mathrm{V} 7 \rightarrow \mathrm{V} 5 \rightarrow \mathrm{V} 4 \rightarrow \mathrm{V} 6$. setelah informasi mengenai rute terbaik diperoleh. Pembaharuan feromon akan dilakukan dengan jumlah pheromon yang baru-baru ditambahkan sebesar $\Delta \mathrm{i}, \mathrm{k}=0.0537$ dengan menggunakan rumus sebagai berikut:

$\mathrm{t}_{\mathrm{ij}}($ baru $)=(1-\mathrm{p}) \cdot\left(\mathrm{t}_{\mathrm{ij}}\right)+\Delta \mathbf{i}, \mathbf{k}$

$$
\begin{aligned}
& \mathrm{t} 2,3=\mathrm{t} 3,2=(1-0,1)(0,0522)+0.0116=0,0638 \\
& \mathrm{t} 3,1=\mathrm{t} 1,3=(1-0,1)(0,0522)+0.0116=0,0638 \\
& \mathrm{t} 1,7=\mathrm{t} 7,1=(1-0,1)(0,0522)+0.0116=0,0638 \\
& \mathrm{t} 7,5=\mathrm{t} 5,7=(1-0,1)(0,0522)+0.0116=0,0638 \\
& \mathrm{t} 5,4=\mathrm{t} 4,5=(1-0,1)(0,0522)+0.0116=0,0638 \\
& \mathrm{t} 4,6=\mathrm{t} 6,4=(1-0,1)(0,0522)+0.0116=0,0638 \\
& \mathrm{t} 6,2=\mathrm{t} 2,6=(1-0,1)(0,0522)+0.0116=0,0638
\end{aligned}
$$

Sehingga diperoleh jejak pheromon yang baru antara titik yang diperoleh pada tabel sebagai berikut:

Tabel 4.17. pheromone antar titik

\begin{tabular}{|c|l|l|l|l|l|l|l|}
\hline Pheromon & \multicolumn{1}{|c|}{ V1 } & \multicolumn{1}{|c|}{ V2 } & \multicolumn{1}{|c|}{ V3 } & \multicolumn{1}{|c|}{ V5 } & V6 & V7 \\
\hline V1 & 0 & 0.0638 & 0.0638 & 0.0522 & 0.0522 & 0.0522 & 0.0522 \\
\hline V2 & 0.0638 & 0 & 0.0638 & 0.0522 & 0.0522 & 0.0522 & 0.0522 \\
\hline V3 & 0.0638 & 0.0522 & 0 & 0.0522 & 0.0522 & 0.0522 & 0.0638 \\
\hline V4 & 0.0522 & 0.0522 & 0.0522 & 0 & 0.0638 & 0.0522 & 0.0638 \\
\hline V5 & 0.0522 & 0.0522 & 0.0522 & 0.0638 & 0 & 0.0522 & 0.0522 \\
\hline V6 & 0.0522 & 0.0522 & 0.0522 & 0.0638 & 0.0522 & 0 & 0.0522 \\
\hline V7 & 0.0522 & 0.0638 & 0.0522 & 0.0522 & 0.0522 & 0.0638 & 0 \\
\hline
\end{tabular}


Hal : 1 - 13

Karena siklus pertama telah selesai dilakukan dan didapatkan pembaharuan feromon, langkah selanjutnya yaitu mencari rute yang lebih baik lagi pada siklus kedua. Jika terdapat rute yang lebih baik dibanding siklus pertama dalam hal ini memiliki panjang rute yang lebih kecil maka feromon akan diperbaharui kembali, namun ketika siklus kedua tidak lebih baik dari pada siklus pertama maka yang diambil adalah rute yang ada pada siklus pertama. Begitupun untuk siklus ketiga,keempat dan seterusnya sampai mencapai NC max atau batas iterasi yang ditentukan. Pada pencarian dengan cara manual hanya terbatas untuk siklus pertama atau iterasi pertama $(\mathrm{NC}=1)$ sehingga diperoleh rute terbaik sementara yaitu $\mathrm{V} 2 \rightarrow$ $\mathrm{V} 3 \rightarrow \mathrm{V} 1 \rightarrow \mathrm{V} 7 \rightarrow \mathrm{V} 5 \rightarrow \mathrm{V} 4 \rightarrow \mathrm{V} 6$. dengan jarak sebesar $85,8 \mathrm{~km}$.

\section{SIMPULAN}

Dari uraian pembahasan tersebut, maka dapat diambil kesimpulan sebagai berikut :

1. Pembentukan model untuk optimasi jalur wisata pada Kota batam dapat dilakukan dengan menggunakan teknik algoritma ant colony untuk 7 titik lokasi wisata yang ditentukan sehingga berdasarkan data yang dimiliki dapat dilakukan pembentukan model jalur optimum untuk jarak terpendek.

2. Dengan algoritma ant colony dapat menghasilkan jalur terpendek yaitu V2 $\rightarrow$ $\mathrm{V} 3 \rightarrow \mathrm{V} 1 \rightarrow \mathrm{V} 7 \rightarrow \mathrm{V} 5 \rightarrow \mathrm{V} 4 \rightarrow \mathrm{V} 6$. dengan jarak sebesar $85,8 \mathrm{~km}$

\section{UCAPAN TERIMAKASIH}

Terima kasih kepada Universitas Islam Kuantan Singingi yang memberikan kesempatan kepada saya untuk menerbitkan Jurnal di JTOS. Serta terima kasih kepada Universitas Putera Batam, teman-teman, danpihak yang terkait telah membantu proses penelitian ini berjalan.

\section{DAFTAR PUSTAKA}

Angga Ginanjar Mabrur, L. R. (2012). Penerapan Data Mining Untuk Memprediksi Kriteria Nasabah Kredit. Jurnal Komputer Dan Informatika (KOMPUTA), 1(1), 53-57.

Chan, A. S., \& Sari, I. U. (2017). Rancang Bangun Aplikasi Wisata Kuliner Halal Berbasis Android Pada Negara Singapura, 9(2), 1323-1334.

Chen, L., Xiao, C., Li, X., Wang, Z., \& Huo, S. (2018). A seismic fault recognition method based on ant colony optimization. Journal of Applied Geophysics, 152, 1-8. https://doi.org/10.1016/j.jappgeo.2018.02.009

Jiao, Z., Ma, K., Rong, Y., Wang, P., Zhang, H., \& Wang, S. (2018). A path planning method using adaptive polymorphic ant colony algorithm for smart wheelchairs. Journal of Computational Science, 50-57. https://doi.org/10.1016/j.jocs.2018.02.004

Lorena, S., Zarman, W., \& Hamidah, I. (2014). Analisis Dan Penerapan Algoritma C4.5 Dalam Data Mining Untuk Memprediksi Masa Studi Mahasiswa Berdasarkan Data Nilai Akademik. Prosiding Seminar Nasional Aplikasi Sains Dan Teknologi (SNAST), (November), 263-272. https://doi.org/10.5829/idosi.weasj.2015.6.2.22162

Maryati, I., \& Wibowo, H. K. (2012). Optimasi penentuan rute kendaraan pada sistem 
distribusi barang dengan ant colony optimization. Seminar Nasional Teknlogi Infromasi \& Komunikasi Terapan 2012, 2012(Semantik), 163-168.

Melo, L., Pereira, F., \& Costa, E. (2014). Extended experiments with ant colony optimization with heterogeneous ants for large dynamic traveling salesperson problems. Proceedings - 14th International Conference on Computational Science and Its Applications, ICCSA 2014, 171-175. https://doi.org/10.1109/ICCSA.2014.39

Ning, J., Zhang, Q., Zhang, C., \& Zhang, B. (2018). A best-path-updating informationguided ant colony optimization algorithm. Information Sciences, 433-434, 142-162. https://doi.org/10.1016/j.ins.2017.12.047

Primadany, S. R., \& Mardiyono, R. (n.d.). ANALISIS STRATEGI PENGEMBANGAN PARIWISATA DAERAH (Studi pada Dinas Kebudayaan dan Pariwisata Daerah Kabupaten Nganjuk). Jurnal Administrasi Publik (JAP), 1(4), 135-143. Retrieved from https://media.neliti.com/media/publications/74232-ID-analisis-strategi-pengembanganpariwisat.pdf

Singkil, K. A. B. A. (2015). Sistem Pendukung Keputusan Pengangkatan Karyawan Tetap Dengan Metode Analytic Hierarchy Process ( Ahp ) Pada Pt . Perkebunan Lembah Bhakti Propinsi Nad, (April), 96-106.

Sitanggang, Y. C., Dewi, C., Wihandika, R. C., Studi, P., Informatika, T., Komputer, F. I., \& Brawijaya, U. (2018). Pemilihan Rute Optimal Penjemputan Penumpang Travel Menggunakan Ant Colony Optimization Pada Multiple Travelling Salesman Problem ( M-TSP ), 2(9), 3138-3145.

Zulkifli, A. (2016). Metode C45 Untuk Mengklarifikasi Pelanggan Perusahaan Telekomunikasi Seluler, 2(1), 65-76. 